\title{
Perancangan Lingkungan Pembelajaran yang Sesuai dengan Metode Pembelajaran di Sekolah Lentera Harapan Rote
}

\author{
Jessica Novia \\ Universitas Pelita Harapan \\ JN0203@student.uph.edu
}

\begin{abstract}
Abstrak
Lingkungan pembelajaran secara fisik turut berpengaruh dalam berjalannya proses pembelajaran yang efektif. Tujuan dari penulisan adalah melihat seberapa sesuai perancangan lingkungan pembelajaran dalam Sekolah Lentera Harapan Rote dengan metode pembelajaran yang digunakan. Penulis menganalisa data proyek Sekolah Lentera Harapan Rote dari berbagai faktor lingkungan pembelajaran secara fisik, dan membandingkannya dengan teori-teori yang berkaitan dengan pembelajaran. Dari hasil penelitian, dapat terlihat faktor-faktor dari lingkungan pembelajaran yang sudah ideal dalam perancangan lingkungan pembelajaran Sekolah Lentera Harapan, serta aspek yang mempengaruhi perancangan lingkungan pembelajaran.
\end{abstract}

Kata kunci: Lingkungan pembelajaran, metode pembelajaran, perancangan sekolah.

\begin{abstract}
Physical learning environment contributes to the effectiveness of learning process. The aim of this research is to see how the designed physical learning environment of Lentera Harapan School Rote corresponds to the learning methods applied. The method used is by analyzing data from Lentera Harapan School Rote project from various factors of physical learning environment and comparing the data to learning theories. From this research, we could see how factors from physical learning environment of Lentera Harapan School Rote contributes to the learning process, and aspects that influence the design of learning environments.
\end{abstract}

Keywords: Learning environment, learning methods, school design.

\section{Pendahuluan}

Sekolah Lentera Harapan merupakan sekolah yang berada di bawah naungan Yayasan Pendidikan Pelita Harapan dan ditujukan bagi anak-anak yang kurang beruntung di seluruh pelosok Indonesia. Sekolah Lentera Harapan kini memiliki 26 sekolah yang tersebar dalam 16 kota di seluruh Indonesia. Salah satunya adalah Sekolah Lentera Harapan Rote, yang terletak di pulau Rote, Nusa Tenggara Timur. SLH Rote memiliki dua jenjang pendidikan yaitu TK dengan tingkatan K2 dan K3, dan SD dengan tingkatan kelas 1-3 SD

Sekolah Lentera Harapan merupakan sekolah bertaraf nasional yang menggunakan kurikulum 2013 dalam proses pembelajarannya. Menurut (UU No 20 Tahun 2003), kurikulum dapat diartikan sebagai pedoman perencanaan dan pengaturan mengenai materi pembelajaran yang disampaikan kepada siswa untuk mencapai tujuan pendidikan. Ada beberapa jenis kurikulum yang diterapkan dalam pendidikan di Indonesia, seperti, Cambridge, Kurikulum 2013, International Baccalaureate, Highscope, dan Montessori. Kurikulum 2013 merupakan kurikulum pemerintah yang mulai diterapkan sejak tahun 2013 di Indonesia.

Setiap kurikulum memiliki metode pembelajaran yang berbeda-beda. Menurut (Sudjana, 2005) metode pembelajaran adalah cara guru berinteraksi dengan siswa dalam proses pembelajaran. Kurikulum 2013 memiliki tiga metode pembelajaran, yaitu project-based learning, problem-based learning, dan discovery learning (Kementerian Pendidikan dan Kebudayaan, 2004). Dalam Sekolah Lentera Harapan, metode pembelajaran ini diterapkan dalam berbagai aktivitas untuk membantu pengajar menyampaikan materi 
kepada siswa. Setiap metode pembelajaran memiliki kebutuhan yang berbeda-beda, baik konfigurasi tempat duduk yang berbeda, maupun fasilitas yang digunakan.

Menurut (Lei, 2010), metode pembelajaran seringkali tidak didukung oleh lingkungan pembelajaran secara fisik yang memadai karena kurang dianggap penting. Perubahan lingkungan secara fisik dapat memengaruhi persepsi siswa akan pembelajaran, lingkungan pembelajaran yang kurang mendukung metode pembelajaran dapat menjadi hambatan dalam proses pembelajaran. Lingkungan pembelajaran yang efektif dapat membantu guru menyampaikan materi pembelajaran dan memegang kendali akan ruang kelas, serta membantu siswa menerima materi pembelajaran dengan baik.

Untuk mendukung jalannya proses pembelajaran yang sesuai dengan kurikulum, lingkungan belajar merupakan salah satu faktor yang penting. Cara pandang anak terhadap suasana lingkungan belajar dapat mempengaruhi pencapaian dan perilaku anak dalam kelas, karena suasana kelas yang positif dan aman secara emosional akan mendorong semangat belajar pada anak dan juga mencegah perilaku yang bermasalah (Vito, 2003). Kondisi lingkungan belajar secara fisik, psikis, dan sosial yang baik akan menjadikan kegiatan pembelajaran lebih efektif, sehingga kurikulum yang diterapkan oleh sekolah dapat diterapkan dengan baik. Setiap sekolah memiliki kurikulum yang berbeda-beda sehingga terdapat perbedaan metode pembelajaran yang digunakan. Sekolah merupakan salah satu lingkungan belajar utama anak-anak, di mana anak-anak menghabiskan sebagian besar waktu mereka. Karena itu, perancangan sekolah perlu disesuaikan dengan metode pembelajaran dari kurikulum yang digunakan.

\section{Metode}

Metode penelitian yang digunakan dalam penulisan adalah metode penelitian kualitatif. Metode yang digunakan penulis untuk mengumpulkan data antara lain adalah studi pustaka, observasi dan wawancara. Melalui studi pustaka, penulis mempelajari mengenai jenis-jenis kurikulum yang digunakan di Indonesia, serta metode pengajaran dan penerapannya dalam ruang kelas. Penulis juga mempelajari mengenai kebudayaan lokal di Rote, seperti mata pencaharian penduduk, teknologi konstruksi lokal, rumah tradisional, dan material lokal. Selain itu, untuk mendukung studi mengenai metode pembelajaran, penulis juga mempelajari teori-teori pembelajaran.

Studi Observasi dilakukan di SLH Curug, SLH Koja, dan SLH Rote. Dalam Observasi SLH Curug dan Koja, penulis mempelajari mengenai alur aktivitas siswa sejak datang hingga pulang sekolah. Dari observasi, penulis mempelajari mengenai cara kerja siswa dalam konfigurasi tempat duduk berkelompok di dalam kelas. Penulis juga mendapatkan informasi mengenai fasilitas yang digunakan dalam kegiatan pembelajaran sehari-hari, seperti loker, papan tulis, meja, kursi, proyektor, dan rak buku. Dalam studi observasi di SLH Rote, penulis mempelajari mengenai aktivitas yang dilakukan di SLH Rote dan perbedaan dengan SLH lainnya.

Penulis mewawancarai pengajar TK dan SD yang bertugas di SLH Curug. Melalui wawancara, penulis mempelajari mengenai penerapan kurikulum 2013 dalam keseharian pembelajaran di SLH Curug, permasalahan yang berkaitan dengan fasilitas di sekolah, dan harapan pengajar akan ruang kelas yang ideal menurut mereka. Kemudian dalam penelitian, penulis membandingkan dan menganalisis data-data dari hasil perancangan Sekolah Lentera Harapan Rote dengan data yang dimiliki penulis melalui studi pustaka, observasi, dan wawancara. data dianalisis berdasarkan teori-teori pembelajaran yaitu, cognitivism, constructivism, dan behaviourism.

\section{Pembahasan}

Sesuai dengan jenjang pendidikan yang tersedia, ruang kelas pada perancangan Sekolah Lentera Harapan Rote berjumlah enam ruang kelas bagi siswa sekolah dasar, dan satu ruang kelas bagi siswa taman kanakkanak. Ruang kelas siswa TK digunakan bergantian pada pagi dan siang hari, antara siswa K2 dan K3. Kebutuhan ruang dalam pelaksanaan metode pembelajaran kurikulum 2013 di ruang kelas. Setiap metode pembelajaran memiliki pelaksanaan yang berbeda-beda sehingga kebutuhan ruang yang diperlukan untuk mendukung proses pembelajarannya juga berbeda. Menurut (Permendikbud No 69 Tahun 2013), kurikulum 2013 memiliki tujuan untuk mempersiapkan manusia Indonesia agar memiliki kemampuan 
hidup sebagai pribadi dan warga Negara yang beriman, produktif, kreatif, inovatif, dan afektif serta mampu berkontribusi pada kehidupan bermasyarakat, berbangsa, bernegara, dan peradaban dunia. Dalam kurikulum 2013, terdapat metode pembelajaran project-based learning, problem-based learning, dan discovery learning.

\section{Project-based Learning}

Dalam metode pembelajaran project-based learning, siswa mengerjakan sebuah proyek dalam jangka waktu tertentu, dan dalam akhir periode akan menghasilkan produk yang merupakan hasil dari pembelajaran. Dalam pendidikan anak usia kecil, kegiatan ini sebagian besar dilakukan secara berkelompok karena menyesuaikan dengan kemampuan anak, sehingga dibutuhkan tempat duduk dengan konfigurasi berkelompok.

\section{Problem-based Learning}

Dalam metode pembelajaran problem-based learning pembelajaran mengangkat permasalahan yang terjadi dalam lingkungan sekitar siswa, dan membahasnya di dalam pembelajaran. Pembahasan masalah dilakukan dengan mengadakan diskusi, baik antara siswa, maupun bersama dengan guru. Untuk menunjang kegiatan berdiskusi, diperlukan konfigurasi tempat duduk secara berkelompok, dan sirkulasi yang memungkinkan bagi guru untuk mengawasi siswa dan turut berdiskusi bersama.

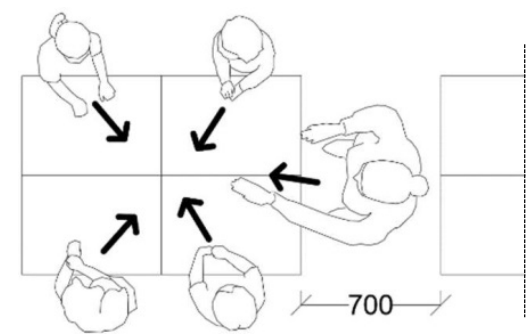

Gambar 1 Ilustrasi Kebutuhan Ruang problem \& project learning

(Novia, 2020)

\section{Discovery Learning}

Metode Pembelajaran discovery learning menuntut siswa untuk mencari informasi-informasi yang dibutuhkan dalam pembelajaran secara mandiri. Meskipun demikian, guru tetap hadir untuk membimbing siswa agar tujuan pembelajaran tercapai. Untuk memungkinkan guru berinteraksi dengan setiap siswa, konfigurasi tempat duduk yang disarankan adalah konfigurasi berbaris menghadap kearah papan tulis, dengan sirkulasi yang memungkinkan bagi guru untuk berinteraksi dengan siswa yang duduk di meja masing-masing.

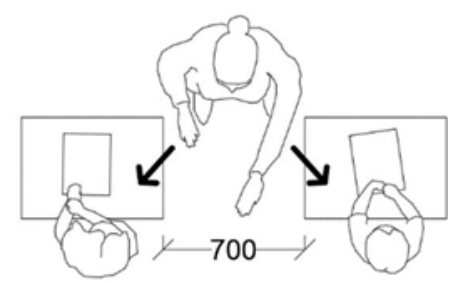

Gambar 2 Ilustrasi Kebutuhan Ruang dsicovery learning

(Novia, 2020) 
Implementasi teori pembelajaran terhadap lingkungan pembelajaran secara fisik dalam ruang kelas Sekolah Lentera Harapan Rote akan dibahas menggunakan teori mengenai faktor-faktor fisik di dalam ruang kelas yang mencakup ukuran ruang, bentuk ruangan, pengaturan tempat duduk \& furnitur, teknologi, pencahayaan, kondisi termal, warna, dan kebisingan.

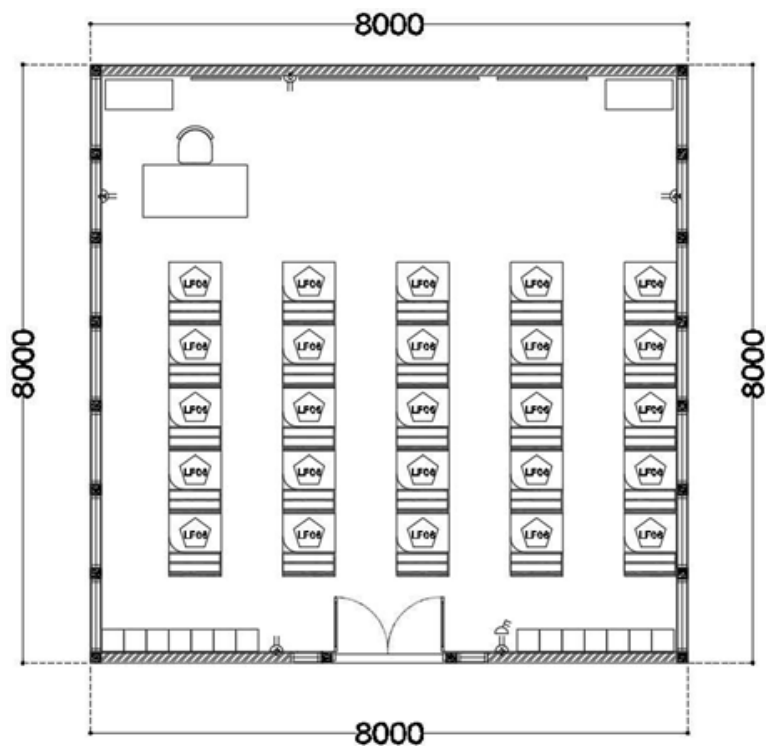

Gambar 3 Denah Kelas SD

(Ruth Oppusunggu, 2020)

\section{Konfigurasi Ruang}

Ruang kelas Sekolah Dasar dan Taman Kanak-kanak terdiri dari satu modul berukuran $8 \mathrm{~m} \times 8 \mathrm{~m}$, dengan total luas area yang sama, yaitu $64 \mathrm{~m}^{2}$. Satu ruang kelas SD digunakan oleh maksimal 30 siswa, sehingga luas ruang yang dibutuhkan adalah $30 \times 2 \mathrm{~m}^{2}$, yaitu $60 \mathrm{~m}^{2}$. Maka luas ruang kelas sudah mencukupi untuk digunakan 30 orang siswa SD. Jumlah siswa TK dalam satu kelas adalah 15 orang, sehingga luas ruang minimum bagi satu ruang kelas TK adalah $48.75 \mathrm{~m}^{2}$ dan luas ruang ideal bagi ruang kelas TK adalah $60 \mathrm{~m}^{2}$. Maka dapat disimpulkan bahwa luas ruang kelas sudah ideal untuk digunakan oleh 15 orang siswa dalam satu kelas.

Tabel 1 Perbandingan luas ruang kelas SLH Rote dengan luas ruang kelas ideal (Novia, 2020)

\begin{tabular}{|l|l|l|l|l|l|}
\hline \multirow{2}{*}{} & \multicolumn{2}{|c|}{$\begin{array}{c}\text { Sekolah Dasar } \\
(30 \text { siswa) }\end{array}$} & \multicolumn{2}{c|}{$\begin{array}{c}\text { Taman Kanak-kanak } \\
\text { (15 siswa) }\end{array}$} & keterangan \\
\cline { 2 - 5 } & $\begin{array}{c}\text { Luas } \\
\text { rancangan }\end{array}$ & $\begin{array}{l}\text { Luas } \\
\text { ideal }\end{array}$ & $\begin{array}{c}\text { Luas } \\
\text { rancangan }\end{array}$ & $\begin{array}{r}\text { Luas } \\
\text { ideal }\end{array}$ & \\
\hline $\mathrm{m}^{2} /$ siswa & 2.14 & 2 & 4.27 & 4 & $\begin{array}{l}\text { Luas ruang kelas siswa TK dan } \\
\text { SD sudah ideal }\end{array}$ \\
\hline $\begin{array}{l}\text { Total area } \\
\left(\mathrm{m}^{2}\right)\end{array}$ & 64 & 60 & 64 & 60 & \\
\hline
\end{tabular}


Pada proses pembelajarannya, Sekolah Lentera Harapan Rote menggunakan metode pembelajaran kurikulum 2013, yaitu problem-based learning, project-based learning, dan, discovery learning. Ketiga metode pembelajaran tersebut berkaitan dengan teori pembelajaran behaviourism, constructivism, dan cognitivism. Pada ruang kelas yang dirancang untuk Sekolah Lentera Harapan Rote, terdapat dua jenis konfigurasi tempat duduk, yaitu konfigurasi berkelompok berhadap-hadapan dan konfigurasi berbaris ke depan.

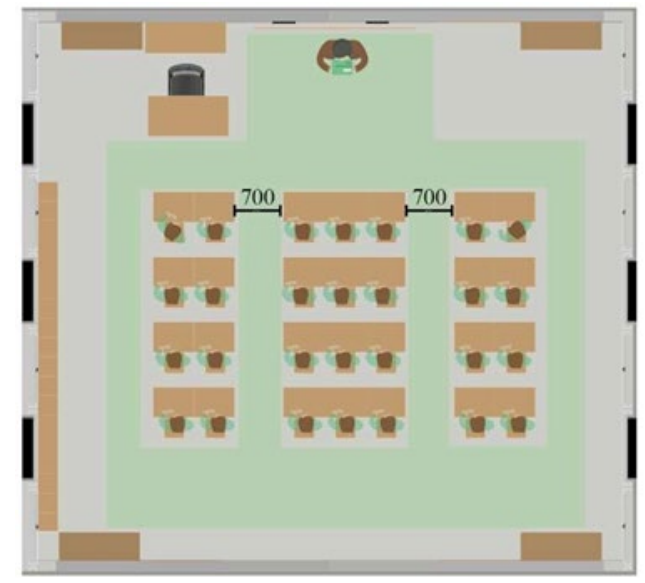

sirkulasi guru

Gambar 4 Denah Kelas SD Konfigurasi Berbaris

(Novia, 2020)

Konfigurasi tempat duduk berbaris menghadap ke arah papan tulis mendukung kegiatan pembelajaran ketika guru menyampaikan materi kepada siswa, dan mendukung cara guru mengatur kondisi ruang kelas yang menerapkan teori behaviourism. Interaksi antar siswa terbatas dengan teman sebangku, dan guru lebih memiliki kontrol akan kondisi ruang kelas karena lebih mudah mengawasi siswa. Konfigurasi ini sesuai dengan metode pembelajaran di Sekolah Lentera Harapan yang juga menerapkan teori behaviourism ketika guru memberi penjelasan di depan kelas. Penerapan teori ini terlihat dalam cara guru mengatur kondisi ruang kelas.

Ketika siswa mulai ribut, guru seringkali memberi respons negatif kepada siswa seperti tidak mengizinkan mereka mengikuti kegiatan yang diikuti teman-temannya, dan tidak memulai kegiatan pembelajaran sebelum kondisi kelas tenang. Sebaliknya, ketika anak-anak menunjukkan sikap yang baik, guru akan memberikan respons positif. Sebelum anak-anak memulai sebuah kegiatan, guru akan meminta anak-anak untuk tenang, dan anak dengan sikap tenang yang baik dapat memulai atau mempersiapkan diri untuk kegiatan tersebut terlebih dahulu, sedangkan anak dengan sikap yang kurang baik harus menunggu lebih lama di tempatnya sampai anak tersebut sudah menunjukkan sikap yang baik.

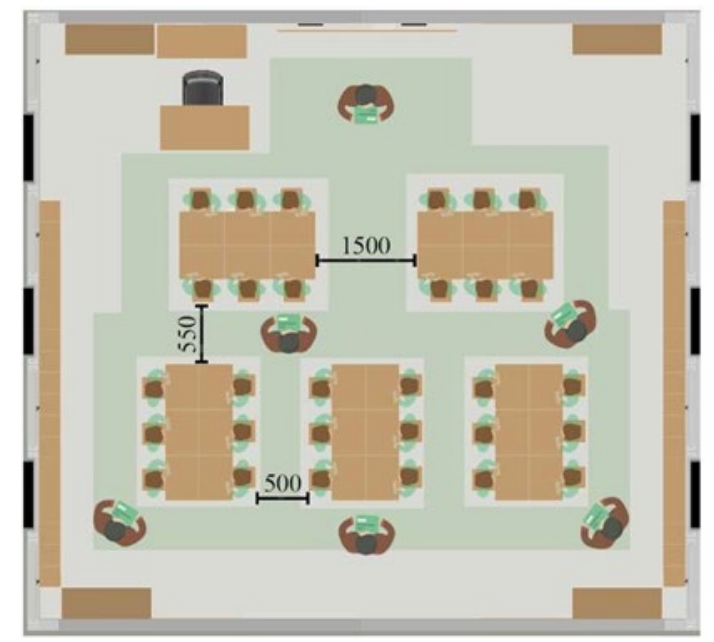

sirkulasi guru

Gambar 5 Denah Kelas SD Konfigurasi Berkelompok

(Novia, 2020) 
Pada konfigurasi berkelompok, siswa yang duduk membelakangi guru perlu memutar kursinya untuk melihat penjelasan guru, sehingga kurang sesuai untuk aktivitas belajar mengajar ketika guru memberi penjelasan di papan tulis. Meskipun demikian, konfigurasi ini mendukung siswa untuk berinteraksi dalam kelompok. Konfigurasi tempat duduk berkelompok mendukung metode pembelajaran problem-based learning dan project-based learning dalam kurikulum 2013, dimana anak-anak seringkali bekerja dalam kelompok dalam proses pembelajaran. Dalam Sekolah Lentera Harapan, problem-based learning diterapkan dengan mengangkat sebuah permasalahan yang berkaitan dengan materi pembelajaran. Kemudian, siswa dibimbing guru untuk mencari solusi dari permasalahan yang diangkat. Metode problem-based learning ini juga dapat diterapkan bersama metode project-based learning dimana pencarian solusi dari permasalahan yang diangkat menjadi sebuah proyek yang dikerjakan oleh siswa dalam bimbingan guru.

Konfigurasi ini juga mendukung proses pembelajaran sesuai teori constructivism, dimana anak-anak dapat belajar secara aktif melalui interaksi mereka dengan teman-temannya dan memperoleh informasi baru melalui interaksi tersebut. Dalam pembelajaran sesuai teori constructivism, guru berperan untuk mengawasi dan membimbing murid dalam pembelajaran. Dalam hasil perancangan, jarak antara kursi siswa beragam, mulai dari $50 \mathrm{~cm}$ hingga $150 \mathrm{~cm}$. Menurut (Julius Panero, Martin Zelnik, 1979) lebar sirkulasi ini sudah cukup bagi sirkulasi lateral orang dewasa yang minimal memiliki lebar $45.7 \mathrm{~cm}$.

Pada ruang kelas TK, konfigurasi tempat duduk yang digunakan adalah konfigurasi berkelompok, dengan anggota setiap kelompok berjumlah empat orang siswa. Tidak seperti ruang kelas SD yang memiliki dua jenis konfigurasi, ruang kelas TK hanya memiliki satu jenis konfigurasi tetap. Hal ini dikarenakan aktivitas yang dilakukan oleh siswa Taman Kanak-Kanak umumnya adalah aktivitas berkelompok.

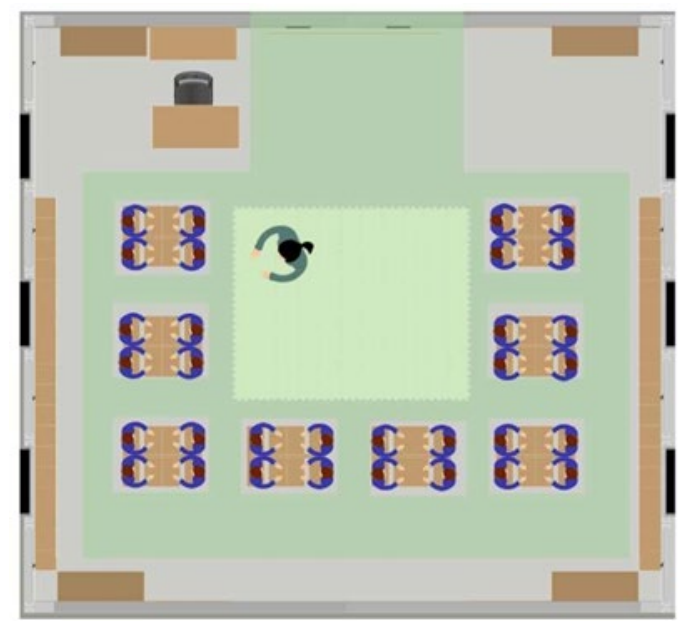

sirkulasi guru

Gambar 6 Ilustrasi Aktivitas Mengerjakan Tugas Dalam Kelas TK

(Novia, 2020)

Meja dan kursi siswa SD pada awalnya akan menggunakan meja dan kursi eksisting yang terbuat dari bahan kayu. Menurut hasil wawancara penulis dengan guru Sekolah Dasar Lentera Harapan Curug, meja dan kursi yang digunakan seringkali memiliki bagian yang mudah lepas, sehingga cukup membahayakan bagi siswa. Material kayu yang digunakan ini cukup berat dan akan sulit untuk mengubah konfigurasi tempat duduk siswa yang seringkali perlu diubah. Namun, pada fase berikutnya meja dan kursi siswa SD rencananya akan diganti menggunakan furnitur SALA yang dikembangkan bagi siswa SD. meskipun furnitur SALA lebih modular dan mudah dipindahkan, namun konfigurasi yang dapat tersusun juga terbatas. Dengan furnitur SALA, konfigurasi meja berkelompok dibatasi dalam jumlah empat orang. Furnitur sala juga tidak memiliki sandaran, sehingga tidak mendukung postur duduk yang baik dan dapat menjadi tidak nyaman jika digunakan dalam waktu lama oleh anak-anak, terutama karena siswa SD menghabiskan waktu enam hingga delapan jam di sekolah. 


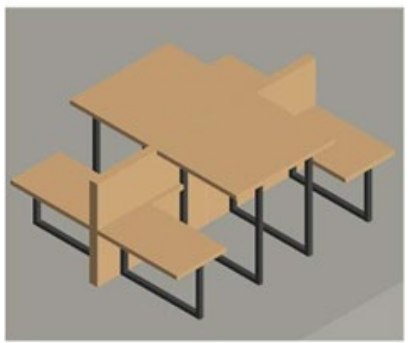

Furnitur SALA dalam konfigurasi berkelompok, terdiri dari 4 meja yang digabungkan
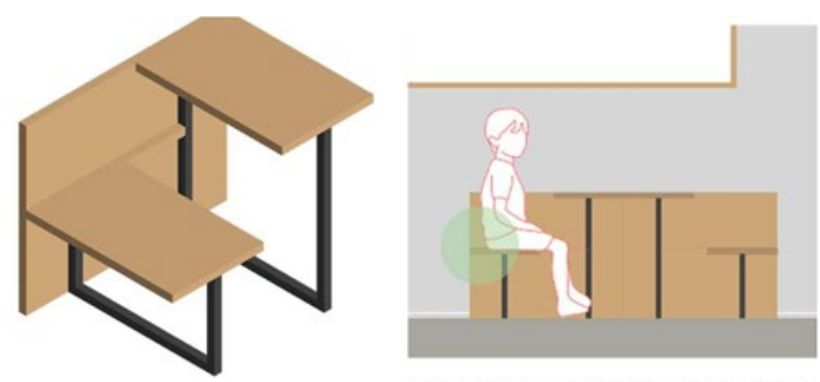

Ilustrasi pengguna furnitur, tidak adanya backrest dapat menyebabkan pengguna merasa tidak nyaman jika duduk dalam jangka waktu yang lama.

Gambar 7 Ilustrasi Furnitur SALA

(Novia, 2020)

\section{Pencahayaan}

Sebagai sumber pencahayaan utama, SLH Rote menggunakan pencahayaan alami yang didapat dari jendela dan skylight, dan sebagai pencahayaan buatan sebagai tambahan ketika cuaca buruk. Iklim di pulau Rote pada umumnya memiliki curah hujan yang sedikit, karena itu pencahayaan alami dapat menjadi sumber pencahayaan utama. Pada plafon setiap ruang kelas terdapat skylight yang berukuran $75 \times 75 \mathrm{~cm}$. Atap skylight menggunakan atap metal transparan yang kemudian ditambahkan akrilik putih pada bagian plafonnya sebagai diffuser agar tidak silau. Selain skylight, terdapat jendela di sepanjang bagian samping kiri dan kanan kelas. Jendela pada bagian samping berukuran $40 \times 100 \mathrm{~cm}$.

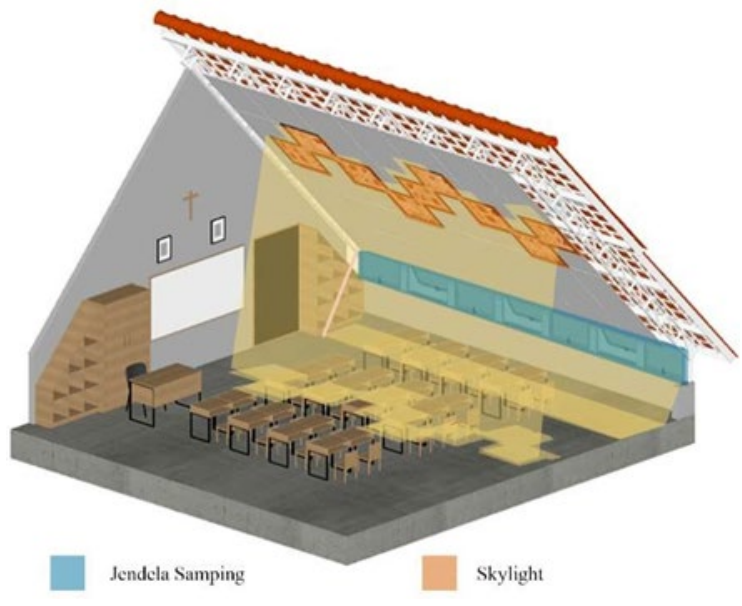

Gambar 8 Ilustrasi pencahayaan alami ruang kelas

(Novia, 2020)

Sebagai pendukung pencahayaan alami, terdapat tiga buah lampu TL yang digunakan ketika pencahayaan alami tidak memadai. Lampu digantung dengan ketinggian $2.3 \mathrm{~m}$ dari lantai pada bagian tengah ruangan untuk mempermudah kegiatan pemeliharaan. Setiap lampu diberi jarak sebanyak $2.37 \mathrm{~m}$ dari bagian tengah lampu ke bagian tengah lampu yang bersebelahan. Jenis lampu yang digunakan adalah lampu LED tube light T8 $2 \times 16 \mathrm{~W}$. 


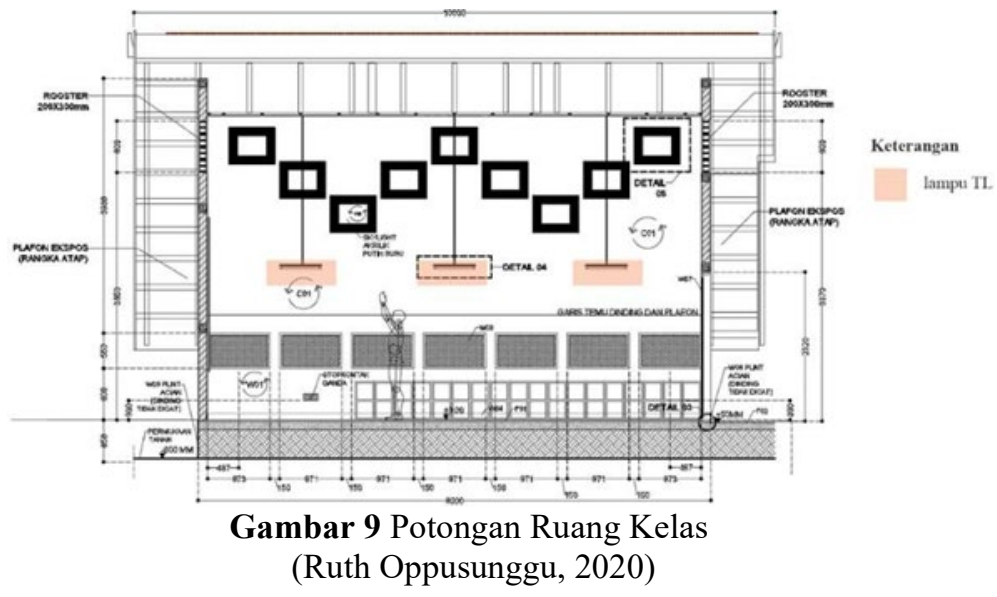

\section{Warna}

Secara umum, ruang kelas TK dan SD memiliki warna yang netral. Plafon memiliki warna utama putih dengan corak merah dan hitam di sekeliling skylight sebagai elemen dekoratif. Furnitur yang digunakan sebagian besar memiliki bahan dasar maupun finishing bermotif kayu, sehingga memiliki kesan alami dan netral. Dinding memiliki finishing berupa cat berwarna abu-abu muda, dan lantai menggunakan keramik berwarna abu-abu tua berukuran $45 \times 45 \mathrm{~cm}$. Penggunaan warna netral di dalam kelas sesuai dengan teori behaviourism yang digunakan di SLH Rote. Warna netral dapat membantu menciptakan suasana kelas yang lebih tenang, sehingga guru dapat lebih mudah mengatur kondisi kelas. Warna cerah yang digunakan sebagai aksen pada skylight dan karya anak yang dipajang pada push-pin board dapat menstimulasi anak untuk berpartisipasi aktif di dalam kelas. Penggunaan aksen warna cerah dapat mendukung teori cognitivism dan constructivism yang mendorong anak-anak menjadi pelajar yang aktif dalam proses pembelajaran.

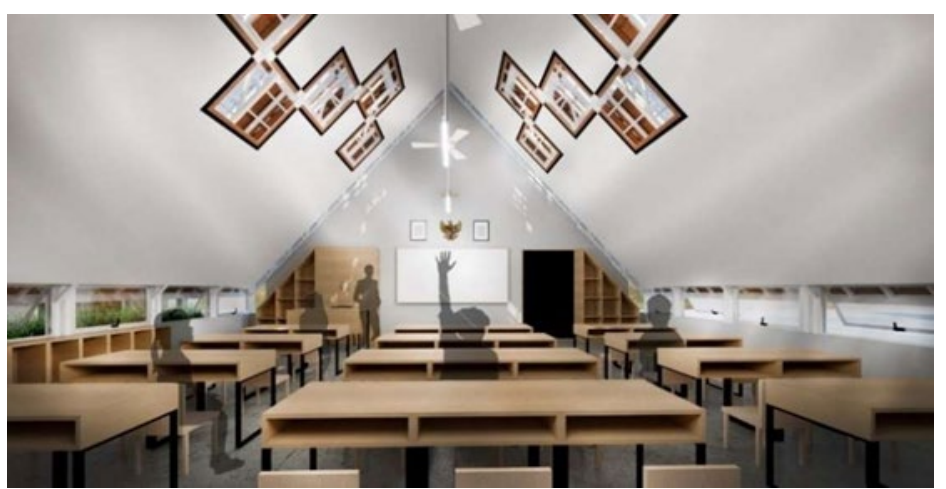

Gambar 10 Perspektif Interior Kelas SD

(Novia, 2019)

Pada ruang kelas TK, terdapat puzzle mat berwarna cerah yang digunakan sebagai area berkumpul bagi anak-anak. Perbedaan warna ini juga menunjukkan fungsi dari area puzzle mat yang digunakan oleh anak-anak untuk berinteraksi bersama guru dan teman-temannya. Pada area mengerjakan tugas, warna yang digunakan tetap bersifat netral sehingga anak-anak dapat lebih fokus. Warna dinding yang netral pada keseluruhan ruang kelas juga dipersiapkan untuk menetralisir warna-warna cerah dari karya-karya siswa yang akan dipajang di ruang kelas nantinya.

Meskipun penggunaan warna dalam ruang kelas fisik dapat mempengaruhi psikologis siswa, namun, kondisi dalam ruang kelas sebagian besar dipengaruhi oleh lingkungan pembelajaran sosial dan psikis yang dialami siswa dalam proses pembelajaran. Pengalaman siswa dalam kelas akan mempengaruhi tindakan yang mereka lakukan, siswa akan lebih aktif berpartisipasi dalam pembelajaran ketika mereka merasa aman secara emosional. Sehingga, pengaruh warna dalam kondisi ruang kelas kurang berkontribusi dalam menjaga kondisi pembelajaran. 


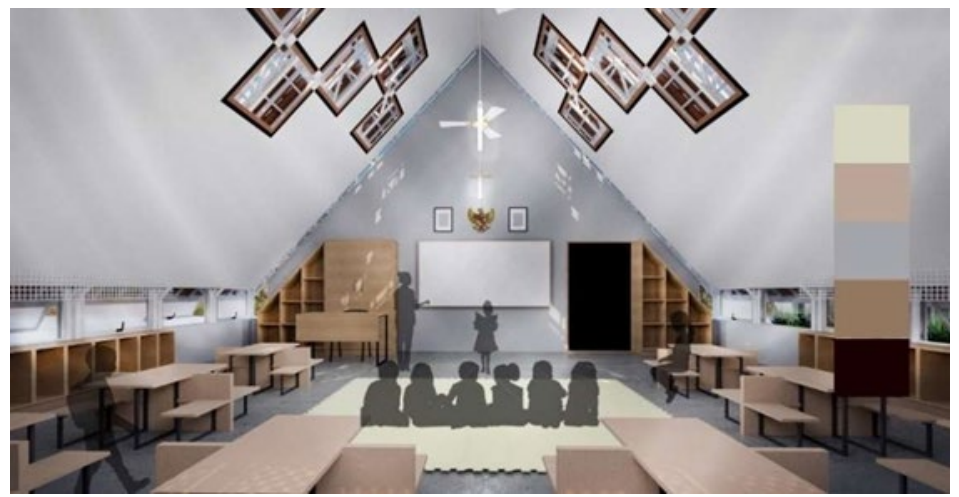

Gambar 11 Perspektif Interior Kelas TK

(Novia, 2019)

\section{Faktor Lingkungan}

Sekolah Lentera Harapan Rote memiliki lokasi yang berjarak sekitar 1750 m dengan Bandar Udara D.C. Saudale. Karena itu, lokasi Sekolah Lentera Harapan Rote berada dalam zona kebisingan sedang dengan tingkat kebisingan berkisar 75-80 dB, tingkat kebisingan belum sesuai dengan standar pemerintah yaitu $55 \mathrm{~dB}$. Karena kedekatan site dengan bandar udara, terdapat potensi terjadinya kebisingan dalam ruang kelas akibat aktivitas pesawat yang melintas di sekitar sekolah. Hal ini dapat menjadi hambatan dalam proses pembelajaran, terutama kegiatan yang berkaitan dengan memecahkan masalah, membaca, dan mengingat.

Kemampuan anak-anak untuk menangkap informasi secara verbal berkurang lebih banyak dibandingkan orang dewasa, ketika kondisi bising. Kemampuan untuk mendengar dalam kondisi bising akan menjadi lebih baik seiring pertumbuhan anak. Menurut Pujol dkk (2014), kebisingan akan mempengaruhi kemampuan anak untuk memecahkan masalah, membaca, dan mengingat, terutama pada lingkungan dengan tingkat kebisingan tinggi seperti dekat dengan bandar udara dan jalanan yang sibuk. Penempatan lingkungan pembelajaran di tempat yang bising, seperti bandara, juga dapat berpengaruh terhadap perkembangan kognitif anak secara jangka panjang. Menurut (Gusrianda, 2019) kawasan kebisingan di sekitar bandar udara terbagi menjadi tinggi $(80<\mathrm{dB})$, sedang $(75-80 \mathrm{~dB})$, dan rendah $(70-75 \mathrm{~dB})$. Kawasan dengan tingkat kebisingan tinggi berjarak $1 \mathrm{~km}$ dari bandara, sedang $2 \mathrm{~km}$, dan rendah $3 \mathrm{~km}$. Sedangkan menurut ( KEPMEN Lingkungan Hidup, 1996), baku tingkat kebisingan untuk lingkungan sekolah dan sejenisnya adalah $55 \mathrm{~dB}$.

Lingkungan psikologis mencakup area kognitif, yaitu keterampilan dan materi yang akan dipelajari, dan keadaan emosional serta motivasi belajar siswa. Menurut (Kamb, 2012) Suasana kelas adalah perasaan, sikap, standar, dan intonasi yang dirasakan oleh pendidik dan siswa ketika berada di dalam ruang kelas. Suasana kelas negatif terasa tidak ramah, kacau, dan tidak teratur. Sedangkan suasana kelas positif adalah suasana kelas yang ramah, aman, layak, dan mendukung pembelajaran siswa. Menurut John M. Vitto (2003), lingkungan pembelajaran dengan suasana positif dapat membuat anak-anak merasa aman untuk terlibat di dalamnya. Suasana positif ini penting terutama pada pendidikan anak usia dini, dimana anakanak perlu lingkungan pembelajaran yang terasa familiar karena merupakan masa transisi dari keseharian mereka di rumah memasuki usia bersekolah.

\section{Simpulan}

Untuk mencapai proses pembelajaran yang efektif, faktor lingkungan fisik juga memiliki peran penting bersamaan dengan lingkungan psikologis dan sosial. Dengan adanya lingkungan fisik yang memadai, maka faktor psikologis dan sosial juga dapat terakomodasi. Berdasarkan analisis mengenai keterkaitan hasil perancangan lingkungan pembelajaran fisik Sekolah Lentera Harapan Rote dengan metode pembelajaran yang digunakan, secara umum perancangan ruang kelas dan koridor SLH Rote sudah sesuai dengan metode pembelajaran yang digunakan. 
Tabel 2 Kesimpulan analisa Sumber: (Novia, 2020)

\begin{tabular}{|c|c|c|c|}
\hline $\begin{array}{l}\text { Aspek } \\
\text { Lingkungan } \\
\text { Pembelajaran } \\
\text { Fisik }\end{array}$ & Ruang Kelas SD & Ruang Kelas TK & $\begin{array}{l}\text { PengaruhTeori } \\
\text { Pembelajaran dan } \\
\text { Kurikulum } 2013\end{array}$ \\
\hline Ukuran Ruang & \multicolumn{2}{|c|}{$\begin{array}{l}\text { Luas ruang kelas yang ada }\left(64 \mathrm{~m}^{2}\right) \text { sudah } \\
\text { melebihi luas ideal yaitu } 60 \mathrm{~m}^{2} .\end{array}$} & $\begin{array}{l}\text { Pada metode } \\
\text { pembelajaran } \\
\text { dalam kurikulum } \\
2013\end{array}$ \\
\hline Bentuk Ruang & \multicolumn{2}{|c|}{$\begin{array}{l}\text { Bentuk ruang sudah mendukung kenyamanan } \\
\text { visual, namun faktor ini juga perlu didukung } \\
\text { oleh konfigurasi tempat duduk. }\end{array}$} & $\begin{array}{l}\text { diperlukan ukuran } \\
\text { dan bentuk ruang } \\
\text { yang dapat } \\
\text { menunjang } \\
\text { sirkulasi guru di } \\
\text { dalam kelas, } \\
\text { karena peran guru } \\
\text { yang penting } \\
\text { dalam } \\
\text { membimbing dan } \\
\text { mengawasi siswa } \\
\text { selama } \\
\text { pembelajaran. }\end{array}$ \\
\hline $\begin{array}{l}\text { Konfigurasi } \\
\text { Tempat Duduk }\end{array}$ & $\begin{array}{l}\text { - Konfigurasi tempat } \\
\text { duduk berbaris } \\
\text { menghadap papan } \\
\text { tulis sudah } \\
\text { mendukung } \\
\text { kenyamanan visual, } \\
\text { serta mendukung } \\
\text { pengawasan guru } \\
\text { dalam ruang kelas } \\
\text { sesuai dengan teori } \\
\text { behaviourism dan } \\
\text { metode } \\
\text { pembelajaran } \\
\text { discovery learning. } \\
\text { Konfigurasi tempat } \\
\text { duduk berkelompok } \\
\text { dengan jumlah } \\
\text { setiap kelompok } 6 \\
\text { siswa, sesuai } \\
\text { dengan teori } \\
\text { pembelajaran } \\
\text { constructivism dan } \\
\text { cognitivism, selain } \\
\text { itu juga sesuai } \\
\text { dengan metode } \\
\text { pembelajaran } \\
\text { project-based } \\
\text { learning dan } \\
\text { problem-based } \\
\text { learning. }\end{array}$ & $\begin{array}{l}\text { Pembagian ruang } \\
\text { menjadi area } \\
\text { berkumpul dan area } \\
\text { mengerjakan } \\
\text { tugasmendukung } \\
\text { kenyamanan visual } \\
\text { anak dalam } \\
\text { memperhatikan guru } \\
\text { dan mengerjakan } \\
\text { tugas. }\end{array}$ & $\begin{array}{l}\text { Dalam Kurikulum } \\
2013 \text { dibutuhkan } \\
\text { konfigurasi tempat } \\
\text { duduk yang } \\
\text { mendukung } \\
\text { terjadinya } \\
\text { interaksi antar } \\
\text { siswa dan guru, } \\
\text { dalam jenjang } \\
\text { SekolahnDasar, } \\
\text { diperlukan } \\
\text { konfigurasi tempat } \\
\text { duduk tambahan } \\
\text { Yang dapat } \\
\text { mendukung } \\
\text { penyampaian } \\
\text { materi kepada } \\
\text { siswa dengan } \\
\text { efektif. }\end{array}$ \\
\hline
\end{tabular}




\begin{tabular}{|c|c|c|c|}
\hline \multirow[t]{2}{*}{ Furnitur } & $\begin{array}{l}\text { Furnitur yang ada } \\
\text { sudah menunjang teori } \\
\text { pembelajaran } \\
\text { constructivism yang } \\
\text { diterapkan dalam } \\
\text { metode pembelajaran. } \\
\text { Pengaturan furnitur } \\
\text { yang memungkinkan } \\
\text { sirkulasi guru juga } \\
\text { memungkinkan } \\
\text { pengawasan guru } \\
\text { terhadap siswa. }\end{array}$ & $\begin{array}{l}\text { Furnitur pada ruang } \\
\text { kelas TK mendukung } \\
\text { teori pembelajaran } \\
\text { constructivism dan } \\
\text { memungkinkan } \\
\text { pengawasan guru } \\
\text { terhadap siswa. }\end{array}$ & $\begin{array}{l}\text { Dari faktor } \\
\text { futnitur, } \\
\text { diperlukan sarana } \\
\text { penyimpanan yang } \\
\text { dapat } \\
\text { mengakomodasi } \\
\text { peralatan yang } \\
\text { dibawa siswa ke } \\
\text { sekolah, seperti } \\
\text { tas, bekal, dan } \\
\text { peralatan } \\
\text { keterampilan yang } \\
\text { ditinggal di dalam } \\
\text { kelas. }\end{array}$ \\
\hline & $\begin{array}{l}\text { Namun, penggunaan } \\
\text { meja dan kursi siswa } \\
\text { eksisting dapat } \\
\text { membahayakan siswa } \\
\text { karena memiliki } \\
\text { bagian-bagian yang } \\
\text { mudah lepas dan berat. } \\
\text { Sedangkan usulan } \\
\text { penggunaan furnitur } \\
\text { SALA bagi siswa SD } \\
\text { belum ideal secara } \\
\text { ergonomi. }\end{array}$ & & $\begin{array}{l}\text { Diperlukan juga } \\
\text { meja dan kursi } \\
\text { dengan ukuran } \\
\text { yang disesuaikan } \\
\text { dengan } \\
\text { antropometri } \\
\text { dan kebutuhan } \\
\text { siswa, sehingga } \\
\text { siswa merasa } \\
\text { nyaman dalam } \\
\text { proses } \\
\text { pembelajaran. }\end{array}$ \\
\hline Teknologi & \multicolumn{2}{|c|}{$\begin{array}{l}\text { Jumlah stopkontak yang tersedia untuk } \\
\text { penggunaan proyektor, speaker, dan alat } \\
\text { elektronik lainnya sudah memadai. Namun, } \\
\text { penggunaan papan tulis sebagai layar proyektor } \\
\text { dapat menyebabkan pantulan pada tampilan } \\
\text { gambar, sehingga gambar yang ditampilkan } \\
\text { menjadi tidak terlihat jelas. }\end{array}$} & $\begin{array}{l}\text { Untuk mendukung } \\
\text { penggunaan } \\
\text { teknologi dalam } \\
\text { pembelajaran, } \\
\text { diperlukan sumber } \\
\text { listrik yang } \\
\text { memadai, selain } \\
\text { itu juga diperlukan } \\
\text { peralatanyang } \\
\text { mendukung } \\
\text { keamanan dan } \\
\text { kenyamanan siswa } \\
\text { dalam } \\
\text { menggunakan } \\
\text { teknologi. }\end{array}$ \\
\hline Pencahayaan & \multicolumn{2}{|c|}{$\begin{array}{l}\text { Penggunaan cahaya alami sebagai sumber } \\
\text { pencahayaan utama dapat memperbaiki } \\
\text { kesehatan siswa baik secara fisik, maupun } \\
\text { psikis, sehingga pembelajaran menjadi lebih } \\
\text { efektif. }\end{array}$} & $\begin{array}{l}\text { Faktor } \\
\text { pencahayaan, } \\
\text { kondisi termal, } \\
\text { warna, dan } \\
\text { kebisingan dapat } \\
\text { mempengaruhi } \\
\text { kondisi psikologis } \\
\text { anak, karena itu } \\
\text { dapat menghambat }\end{array}$ \\
\hline
\end{tabular}




\begin{tabular}{|c|c|c|}
\hline $\begin{array}{l}\text { Kondisi } \\
\text { Termal }\end{array}$ & $\begin{array}{l}\text { Dengan banyaknya ventilasi udara dan } \\
\text { penghawaan mekanik berupa kipas angin, } \\
\text { dapat terjadi cross ventilation untuk membantu } \\
\text { mengatur temperature di dalam ruang. Selain } \\
\text { itu, pertukaran udara yang terjadi dapat } \\
\text { membuat siswa lebih fokus dalam } \\
\text { pembelajaran. }\end{array}$ & $\begin{array}{l}\text { proses } \\
\text { pembelajaran } \\
\text { sesuai teori } \\
\text { constructivism } \\
\text { yang menekankan } \\
\text { proses mental } \\
\text { dalam } \\
\text { pembelajaran. } \\
\text { Namun kondisi } \\
\text { psikologis anak } \\
\text { lebih dipengaruhi } \\
\text { oleh lingkungan } \\
\text { pembelajaran } \\
\text { psikis dan sosial } \\
\text { yang }\end{array}$ \\
\hline Warna & $\begin{array}{l}\text { Penggunaan warna netral dengan sedikit corak } \\
\text { warna cerah akan membantu menjaga kondisi } \\
\text { ruang kelas tetap kondusif dalam pembelajaran } \\
\text { dengan tidak menstimulasi siswa secara } \\
\text { berlebihan. }\end{array}$ & $\begin{array}{l}\text { dialami siswa, } \\
\text { dibandingkan } \\
\text { dengan kondisi } \\
\text { fisik ruang kelas. }\end{array}$ \\
\hline Kebisingan & $\begin{array}{l}\text { Sekolah Lentera Harapan Rote memiliki } \\
\text { potensi kebisingan akibat kedekatannya dengan } \\
\text { bandara D.C. Saudale, selain itu ada juga } \\
\text { potensi kebisingan antar ruang kelas yang } \\
\text { berdekatan. }\end{array}$ & \\
\hline
\end{tabular}

Selain dalam ruang kelas, adanya koridor di hasil perancangan Sekolah Lentera Harapan juga sudah sesuai dengan teori pembelajaran constructivism, namun penambahan fasilitas berupa sarana duduk dan permainan dapat lebih menstimulasi terjadinya interaksi sosial. Selain itu, koridor juga memfasilitasi pembelajaran cuci tangan yang diterapkan dalam pembelajaran di Sekolah Lentera Harapan Rote. Melalui hasil Analisa di atas, dapat disimpulkan juga bahwa kesesuaian aspekaspek lingkungan pembelajaran fisik ini dengan metode pembelajaran dipengaruhi oleh berbagai faktor seperti studi, waktu, anggaran, dan transportasi. Selain itu, meskipun aspek pembelajaran secara fisik dapat membantu berjalannya proses pembelajaran, lingkungan pembelajaran secara psikis dan sosial juga turut memiliki kontribusi yang besar. Tidak seluruh faktor dalam lingkungan pembelajaran fisik memiliki kontribusi yang signifikan dalam proses pembelajaran. 


\section{Daftar Pustaka}

KEPMEN Lingkungan Hidup. (1996). KEPMEN Lingkungan Hidup no 48/MENLH/11/1996. Indonesia: Kementerian Lingkungan Hidup.

Gusrianda, I. N. (2019). Analisis Tingkat Kebisingan di Sekitar Bandar Udara Internasional Minangkabau.

Julius Panero, Martin Zelnik. (1979). Human Dimension. Jakarta: Erlangga.

Kamb, R. (2012). Key Factors in Creating a Positive Classroom Climate. Retrieved Maret 4, 2020, from https://www.cfchildren.org/blog/2012/08/key-factors-in-creating-a-positiveclassroom-

Kementerian Pendidikan dan Kebudayaan. (2004). Metode Pembelajaran. Indonesia: Kementerian Pendidikan dan Kebudayaan.

Lei, S. A. (2010). Classroom Physical Design Influencing Students Learning and Evaluation of College Instruction: a Review of Literature.

Permendikbud No 69 Tahun 2013. (n.d.). Kurikulum 2013. Indonesia: Kementerian Pendidikan dan Kebudayaan.

Pujol,Shopie,Jerome,berthillier, Joseph. (2014). Indor Noise Exposure at Home : A Field Study in The Familly of Urban Schoolchildren.

Sudjana, N. (2005). Dasar-Dasar Proses Belajar Mengajar. Bandung: Sinar Baru Algensindo.

UU No 20 Tahun 2003. (n.d.). UU No 20 Tahun 2003. Indonesia: Pemerintah Republik Indonesia.

Vito, J. M. (2003). Relationship Driven Classroom Management. California : Corwin Press. 
Lintas Ruang: Jurnal Pengetahuan \& Perancangan Desain Interior | Vol.7, No.2, Th. 2019 | Hal 1- 13 